\title{
System-technical fundamentals of the structure of state construction supervision in the re- profiling of big urban area
}

\author{
Dmitriy Topchiy ${ }^{*}$ and Andrey Tokarskiy \\ Moscow State University of Civil Engineering, Yaroslavskoe shosse, 26, Moscow, 129337, Russia
}

\begin{abstract}
The stage of construction is one of the main compulsory periods of the life cycle in the formation of construction end-products capital construction projects of various functional purposes. The compulsory assessment of conformity of buildings and structures, as well as design construction, installation, setting up and recycling (demolition) processes associated with buildings and structures is conducted in Russia in the form of state construction supervision. An assessment results in a document certifying conformity of the actual indicators with the requirements of design, normative (industrial) and legislative documents. Conformity is assessed in accordance with procedural rules depending on the functional purpose of the capital construction project. There are two conformity assessment forms that appear to be similar: "construction inspection" and "state construction supervision". They both characterize an approach used to assess the conformity of activities of participants in the construction operations (customers, developers, contractors) on formation of construction end-products - capital construction projects. These terms differ in so far as the construction inspection implies control by the customer of operations of contractors. State construction supervision authorities undertake supervisory (including inspection) activities in order to identify and crack down on violations of the requirements of technological regulations or other normative legal acts and design documents, committed by the key players in the construction investment activities (customer, developer, contractors), with the involvement of state authorities.
\end{abstract}

\section{Introduction}

Almost any complex system can be represented by a structure in which a dynamic interaction occurs between elements of an artificial environment (tangible things and objects), a human factor and the effects of the natural environment.

A system of construction production is such a complex system, designed for the formation of construction products of various functional purposes. The end result of the functioning of the system of construction production is the completed construction object (a

\footnotetext{
Corresponding author: 89161122142@mail.ru
} 
building or a construction of a certain purpose and established quality, which becomes the main indicator of its functional efficiency) [1].

\section{Materials and methods}

The concept of a system of construction production involves the use (for evaluation, organization and management of production and non-production processes of interaction between structural elements of the system) of methods and techniques of system analysis characterized by the following characteristics (figure 1).

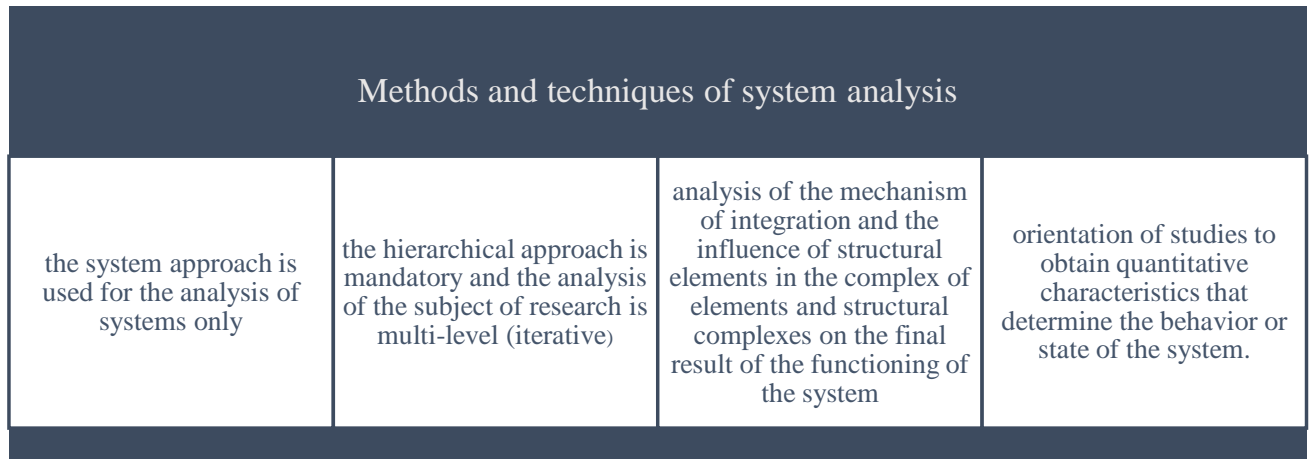

Fig. 1. Methods and techniques of system analysis.

In the adopted formulation of the analysis, the system of construction production is viewed as a complex polyergatic and hierarchical system consisting of a set of less complex subsystems (systems, elements). Each of these subsystems can be considered as an independent object of research [2].

Practical activities of the subject of the territorial bodies of the Russian Federation (authorised to conduct activities related to the implementation of the state construction supervision) is carried out in a variety of structural formats: territorial departments (the chief of management and territorial divisions), territorial service of supervision, inspection (inspection units for territorial and urban entities) state supervision (Gosstroynadzor).

The main tasks to be solved with the involvement of the regional territorial bodies of the Russian Federation are the inspections of the activities of territorial subjects of investment activity in the field of construction (territorial customers, developers, contractors).

The program of checks is developed by officials of the relevant structural divisions (subject territorial authorities of the Russian Federation) - with obligatory accounting of constructive and other features of capital construction object and performance of works on its construction, reconstruction of conditions, town-planning and other factors which are subject to accounting according to requirements of technical regulations (norms and rules), sections of project documentation.

Upon detection of violations as a result of the audit, an act (by the officials of the relevant structural units) is drawn up, which is the basis for issuing to the subject of investment activity in the field of construction of the relevant instructions on the revealed violations, the procedure and conditions for their elimination. In the most General case, the instruction on elimination of violations includes: the characteristic and ID of the revealed violation; the formalized reference to technical regulations (norms, the set of rules) or other type of the regulatory, technological or legal act; section (Chapter, volume, book) of project documentation - the requirements of which are violated during the audit. In the instruction about elimination of the revealed violations the term of elimination of violations is 
specified (established) - taking into account constructive decisions and features of organizational and technological sequence

Table 1 shows the main features of the concept of building production system as a complex polyergatic system.

Table 1. The main features of the polyergatic system.

\begin{tabular}{|c|c|}
\hline $\begin{array}{l}\text { Types of } \\
\text { system } \\
\text { features }\end{array}$ & Qualitative characteristic of the system features \\
\hline Functional & $\begin{array}{l}\text { - presence of a common task and a single goal of functioning for all } \\
\text { elements of the system. } \\
\text { - random nature of external influences that affect the functioning of the } \\
\text { system. } \\
\text { - presence of direct and feedback links between structural elements, the } \\
\text { complex nature of their interaction, especially when influencing external } \\
\text { factors. } \\
\text { - ability of the elements to react to the impact of external factors, } \\
\text { adaptation to changing conditions. } \\
\text { - reliability and stability of a system consisting of various elements with } \\
\text { an uneven degree of reliability. } \\
\text { - ability of the system to develop (move to a higher level) and decline } \\
\text { (transition to a lower level) }\end{array}$ \\
\hline Structural & $\begin{array}{l}\text { - significant number of structural elements that make up the system } \\
\text { - ability to combine into a group (subsystem) on certain established } \\
\text { criteria. } \\
\text { - presence of hierarchical structure and criteria for the operation } \\
\text { - dynamic conditions and relationships. }\end{array}$ \\
\hline Ergonomic & $\begin{array}{l}\text { - subjective nature of decisions. } \\
\text { - possibility of accidental and intentional mistakes } \\
\text { - unpredictability of working capacity, behavior, mood, inability to } \\
\text { predict the results of decisions taken to be implemented. }\end{array}$ \\
\hline
\end{tabular}

At the same time, the main feature of the functioning of the system of construction production (as a polyergic system) is the constantly growing inconsistency of technical characteristics and technological capabilities (of construction machines and means of mechanization, designed to form the building systems of capital construction objects) and indicators of organizational and technological reliability, the established level of quality of construction products during the construction phase.

The system-technical approach to the analysis of the functioning of a single and integral system of construction production presupposes an analysis of the conditions for the interaction of technical, organizational, managerial structural elements oriented towards ensuring the established level of quality of construction products.

The system of "state construction supervision" is (overwhelmingly) mandatory and necessary structural element (subsystem) unified and coherent system of building production.

The examined structural element is designed to perform oversight functions necessary to ensure, to provide the established level of quality, safety and timeliness of the formation of building systems for the projects of capital construction [3].

Table 2 shows the scheme of interaction system (subsystem) "state construction supervision" with the basic structural elements of building production system. 
Table 2. The scheme of interaction of the system (subsystem) of "state construction supervision" with the basic structural elements of the system of construction production.

\begin{tabular}{|c|c|c|}
\hline \multicolumn{3}{|c|}{ Construction management } \\
\hline Construction personnel & $\begin{array}{c}\text { State construction } \\
\text { supervision }\end{array}$ & Machines and mechanisms \\
\hline \multicolumn{3}{|c|}{ Construction organization } \\
\hline
\end{tabular}

The technological sequence of production of construction processes necessary for the construction of capital construction is accompanied by accounting and management of construction processes, checking (control) the quality and volume of execution of production tasks and preparation of the relevant Executive documentation. Deviations from the project documentation are not allowed.

Possible changes (made to the project documentation on the results of the inspection of the structural unit of the state construction supervision) are subject to approval, with the involvement of specialists from the organization that developed the design (technical, technological) documentation for the construction object in question. Specialists of the organization that developed the project documentation, in the prescribed manner (without the need to make changes to the project documentation) carry out supervision.

The admission to practical operation of the built capital construction object is performed after receipt of the act allowing operation of object on the basis of the correlation (final) check of compliance (carried out by offices of structural divisions of the state construction supervision) the actual indicators of functional quality to design values or in the cases provided by Federal laws, provisions of special branch regulations.

The facts of identification of the violations allowed at construction, the characteristic of ways and results of their elimination are brought to interested persons (subjects of investment activity in the field of construction) who will carry out the subsequent operation of capital construction object.

The information obtained as a result of compliance checks in the course of state construction supervision is formalized, normalized and transmitted for generalization and inclusion in the information systems of (Federal and/or regional) state construction supervision. This approach is a notable way of increasing the efficiency of activity of divisions of the state construction supervision (primarily due to the elimination of negative consequences of the overlapping functions of the subjective and the Federal bodies of Executive power). For practical implementation of the considered approach it is expedient to organize in each subject of the Russian Federation information and communication system of interaction of regional public authorities and territorial divisions of Federal authorities. This system focuses on providing the functions of mutual information about the aims, objects and timing of events (programme compliance) with further coordination for the adoption of joint decisions: on the capability of verification; scope, time, duration of inspection; composition and qualifications of the joint inspection team. The technological sequence of production of construction processes necessary for the construction of capital construction is accompanied by accounting and management of construction processes, checking (control) the quality and volume of execution of production tasks and preparation of the relevant Executive documentation. Deviations from the project documentation are not allowed.

Possible changes (made to the project documentation on the results of the inspection of the structural unit of the state construction supervision) are subject to approval, with the involvement of specialists from the organization that developed the design (technical, technological) documentation for the construction object in question. Specialists of the organization that developed the project documentation, in the prescribed manner (without the need to make changes to the project documentation) carry out supervision. 
The admission to practical operation of the built capital construction object is performed after receipt of the act allowing operation of object on the basis of the correlation (final) check of compliance (carried out by offices of structural divisions of the state construction supervision) the actual indicators of functional quality to design values or in the cases provided by Federal laws, provisions of special branch regulations[6].

The facts of identification of the violations allowed at construction, the characteristic of ways and results of their elimination are brought to interested persons (subjects of investment activity in the field of construction) who will carry out the subsequent operation of capital construction object.

The information obtained as a result of compliance checks in the course of state construction supervision is formalized, normalized and transmitted for generalization and inclusion in the information systems of (Federal and/or regional) state construction supervision. This approach is a notable way of increasing the efficiency of activity of divisions of the state construction supervision (primarily due to the elimination of negative consequences of the overlapping functions of the subjective and the Federal bodies of Executive power). For practical implementation of the considered approach it is expedient to organize in each subject of the Russian Federation information and communication system of interaction of regional public authorities and territorial divisions of Federal authorities. This system focuses on providing the functions of mutual information about the aims, objects and timing of events (programme compliance) with further coordination for the adoption of joint decisions: on the capability of verification; scope, time, duration of inspection; composition and qualifications of the joint inspection team.

The system (subsystem) of "state construction supervision" interacts with the systems (subsystems) of "construction management" and "construction organization" of the united and coherent system of building production. The managed impact of the system (subsystem) of "state construction supervision" is implemented with the actions of construction personnel (including operators of construction machines and mechanisms).

The effective functioning of the system (subsystem) of "state construction supervision" is defined as: professional skills and production discipline of the personnel, a rational organization of the internal structure of the service, the quality of interaction with the external (organizational, managerial, expert) structures.

Using the methodology of system analysis seems to be a rational way of determining the essential features of the system (subsystem) of "state construction supervision" as a complex, evolving (taking into account the corresponding object life cycle period for capital construction) and multilevel hierarchical organization.

From the perspective of system analysis, the tasks assigned to the structure (system, subsystem) of the state supervision to ensure the quality of construction products installed, it is necessary to consider and solve them in a holistic context (the efficiency of the functioning of the modern system of construction production), as a result of the interaction of various subjects of investment activity in construction [4].

The investigation of the causes of various problem situations (technical, organizational, managerial, economic, legal, social) associated with the structural features of the system of construction production (as a single and integral system or supersystem) and the system of state construction supervision (as a subsystem) with the aim of increasing the efficiency of their functioning is possible in case of use the following system-technical principles (figure 2). 


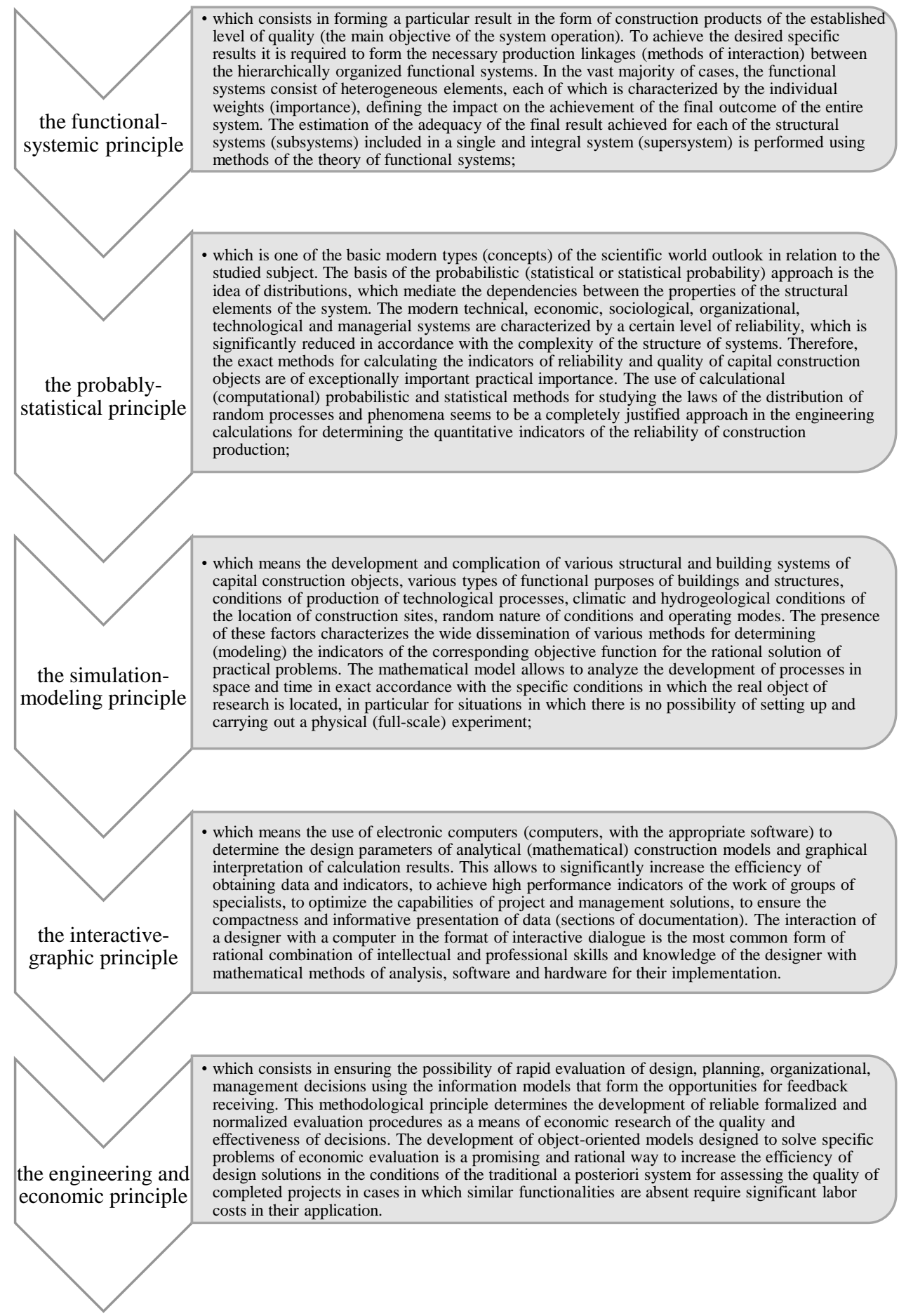

Fig. 2. The list of system-technical principles, which are necessary to use during the investigation of the causes of various problem situations associated with the structural features of the system of construction production. 
Analysis of the functioning of the system (subsystem) of "state construction supervision" allows the application of an arbitrary number of the considered systemtechnical principles (or their combinations), combined with more specific (inherent to the organizational systems) forms and methods of system analysis, based on the conceptual provisions of the general theory of systems.

The need for a system-technical approach to the analysis of the functioning of the organizational-technical (complex) structure has emerged after manifestations of situations in which an individual, even good working elements (subsystems), united by a certain format of interaction, did not constitute a well-functioning system.

In a complex system (subsystem) is often that hotfix of taken decision (or adapting to the actual conditions of the construction site) requires much more expenses than keeping specialists and technical divisions of the system (subsystem) of "state construction supervision". It is for this reason that the process of "monitoring" the object of capital construction is advisable to start with the earliest periods of the life cycle.

The inevitable consequence of this approach is the complexity of the functional loads on the system structures (subsystem) of "state construction supervision", which provides for the use of funds and the results of simulation and experimental modeling of systemoriented analysis methods (system concepts of using modern scientific and technological developments) of the quality of construction products.

\section{Conclusion}

In a significant majority of cases, decisions must be made in the context of the maximum possible consideration of various subjects of investment activity in construction, the existence of explicit and indirect links between them and the surrounding (artificial and natural) environment. The two main conceptual methodological approaches are combined: "a part $\leftrightarrow$ a whole" and "system $\leftrightarrow$ environment".

\section{References}

1. A. Lapidus, I. Abramov, E3S Web of Conferences, 33, 170 (2018)

2. D. Topchiy, V. Skakalov, A. Yurgaitis, IJCIET, 9 (1), 985 (2018)

3. I. Abramov, T. Poznakhirko, A. Sergeev, MATECWebConf, 86, 15 (2016)

4. D. Topchiy, E. Kochurina, System technologies, 1 (26), 107 (2018)

5. D. Topchiy, V. Skakalov, Prospects of science, 10 (97), 44 (2017)

6. P. Oleinik, E3S Web of Conferences, 33, 89 (2018)

7. D. Topchiy, E. Kochurina, System technologies, 1 (26), 107 (2018)

8. B. Zhadanovsky, D. Topchiy, Innovations and investments, 12, 264 (2017) 